\title{
Stabilization OF KaOlinitic Clayey SoIL With Glass Waste ANd Rock Dust Waste Pulverized in High ENERGY MILL
}

\author{
Fábio dos Santos Gusmão ${ }^{1}$, Louise Motta de Oliveira Souza ${ }^{1}$, Letícia Pena Ferreira ${ }^{1}$, \\ Juliano Rodrigues Spínola ${ }^{1}$, Alex Gomes Pereira ${ }^{1}$ and Consuelo Alves da Frota ${ }^{1}$ \\ ${ }^{1}$ Federal University of Amazonas, Research Group of Geotechnical Engineering, Avenue \\ Rodrigo Octávio, 3000, Manaus, Brazil \\ fabiosgusmao67@gmail.com \\ louisemottasouza@gmail.com \\ leticiapenaferreira2@gmail.com \\ julianospinolalo@gmail.com \\ alexgp88@gmail.com \\ cafrota@yahoo.com.br
}

\begin{abstract}
The State of Amazonas, Brazil, presents a historic issue related to road pavements due to the great percentage of clayey soil in subgrades. Because of that, researchers have been searching for alternative solutions aiming the rational use of finite resources and the development of new technologies. In this study, the effects of glass waste and "rock dust" were investigated, both pulverized in high energy mill for stabilization of a typical clayey soil. Accordingly, UCS and tensile strength by diametral compression were conducted on soil specimens together with the addition of 10\% and 50\% of glass and rock. The results showed that $10 \%$ of glass content increased up to $21 \%$ on UCS compared to soil "in natura". Furthermore, by adding "rock dust" waste, the strength also improved up to $60 \%$ on UCS and $8 \%$ on TS. In particular, the mechanical parameters indicated $10 \%$ of content, on either glass or rock waste, to be the effective amount on stabilization of clayey soil.
\end{abstract}

KEYWORDS: clayey soil, rock waste, glass waste, high energy mill.

\section{INTRODUCTION}

The civilization necessity for economic and social development created, alongside time, the demand for continuous displacements, which have on paving one of the structures that provides the referred mobility. However, the available materials for paving, as a rule, do not satisfy the standardized specification. The soil stabilization technique was proposed as an alternative to paving engineering in order to treat the natural material and to reach the indicated levels for construction according with the resistance, compressibility and permeability [1]. This procedure can be performed through chemical processes, adding substances that modify the material behavior from chemical reactions, and granulometric changes, where the combination and manipulation of soils and alternative materials in adequate proportions tend to guarantee greater stability to composition [2].

In this context, the paving studies brought the necessity of rational use of natural and limited resources, and in consequence of scientific development, showed as possible in this knowledge area, the employing of new materials, as well as the use of solid residue, as an improver to the former soil of sublayers of pavement [3]. Some works using the addition of materials such as cement, lime and silica on soil mixture for its treatment can be highlighted. It is also observed that the referred authors employed these materials in nano condition, practice still little used for Geotechnical Engineering and justified by the literature as the absence of study to understand their properties [4-7].

Concerning nanoparticles, they are defined as particles that have at least one dimension within nanometer scale $(1 \mathrm{~nm}$ a $100 \mathrm{~nm})$, capable of actively interacting with other soil constituents, due to their elevated specific superficial area and surface reactive with charges [8]. A stabilizing material can reach such dimensions after their pulverization in high energy mill and, in this way, present significant improvements in geotechnical properties from soil [9]. 
About the obtention of new functionalities to solid residue in geotechnical studies, the works that employed fly ashes from mineral and vegetal coal, polymer fibers, ceramic residue, recycled glass, rock powder and residue of tires as stabilizers stand out [10]. In general, there was success in most quoted studies.

Due to the evidenced problem relevance, and aiming to contribute to improving the paving conditions in Manaus, the present study selected the milled glass waste with silica $\left(\mathrm{SiO}_{2}\right)$ as its main component, and the milled waste from "rock powder", both used as a granulometric stabilizer to the kaolinitic clayey soil, representing the subsoil from Manaus. The source of material is the non-recycled glass bottles and the unused environmental liability from exploration of granite deposits.

\section{Materials AND MethodS}

\subsection{Materials and Characterization}

The soil, which was given by the company "Cerâmica Rio Negro Ltda.", was collected from a deposit in the Amazon region to the production of bricks. In order to prepare the material and perform the characterization tests, the procedures prescribed in NBR 6457/16 [11] were used as reference.

These steps involved pre-drying the soil in the air (Figure 1a), until reach the hygroscopic water content, wrecking (Figure 1b) and sieving the material for each performed test. Typically, plastic visual and tactile characteristics have been found in the soil, that has a slightly reddish tint.

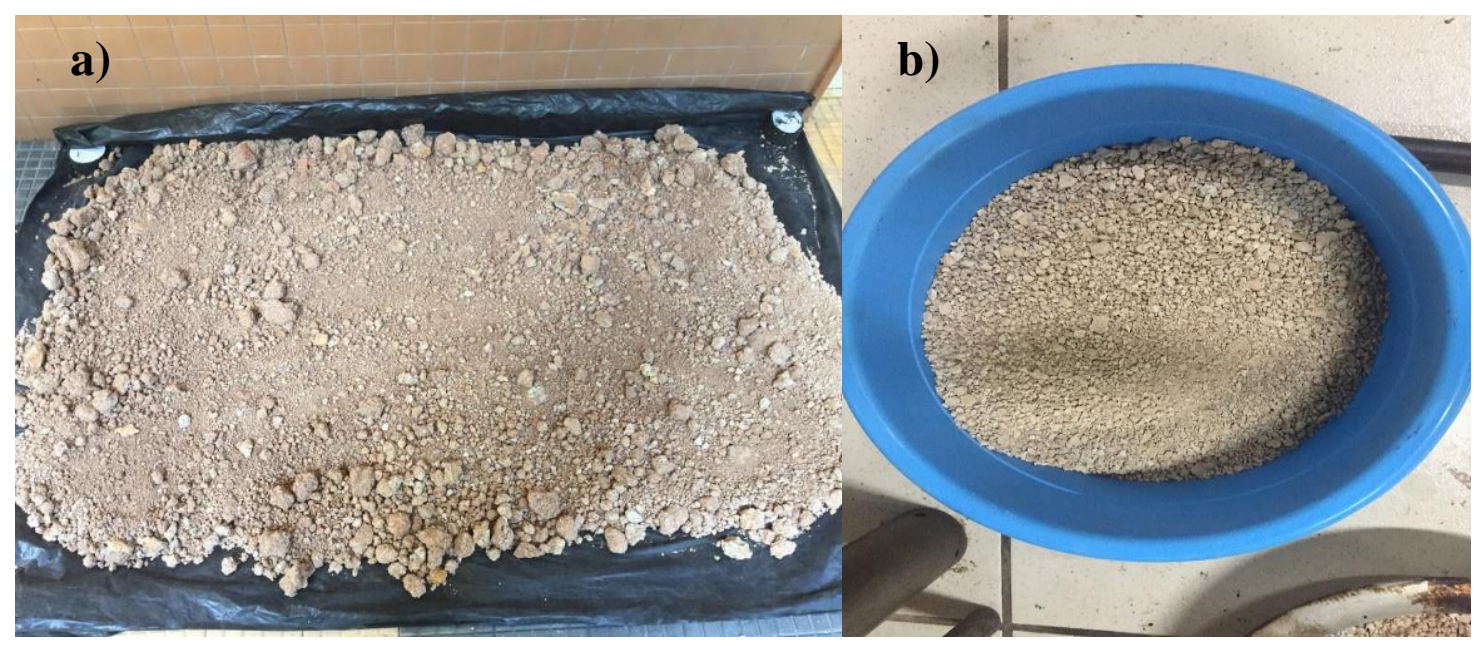

Figure 1: a) Natural soil sample drying; b) Natural soil after wrecked.

Used as a granulometric stabilizer, the glass was obtained from amber-colored bottles, characteristic in alcoholic and soft drink packaging. All material was previously sanitized, sun dried and manually crushed in smaller pieces (Figure 2a). Subsequently, the treatment of this followed in two procedures in order to obtain distinct grain sizes. In the first stage, $5 \mathrm{~kg}$ of crushed glass was used in the "Los Angeles" machine, sieving the resulting sample through sieve no. $40(0.42 \mathrm{~mm})$. From the passing waste, one sample was used in the soil mixture for compaction tests, while other was used in the following milling process. This was made up of pulverization in high energy mill, SPEX SamplePrep 8000M model, in order to use the pulverized waste with the soil in the mechanical tests, in 15 minute syntheses.

Related to the "rock dust", it was a result of the extraction of rock from Moura quarries, located in a district of Amazonas State. Such activity is performed through explosives which produce dust that negatively impacts the agriculture and the hydric water resources. This region is characterized to have igneous consolidated material around its area, represented by gneisses and meta-granites, both widely used in civil construction for gravel production [12]. The rock dust is transported to Manaus by river vessels, and the material is leased inside the ports without proper disposal. In visual analysis, the waste presented an essentially fine granular composition and of greyish color (Figure 2b). Because of that, it was not necessary to submit it to the Los Angeles machine. However, the process of pulverization in high energy mill was still proceeded under 15 minutes syntheses, as well as mentioned with the glass. 


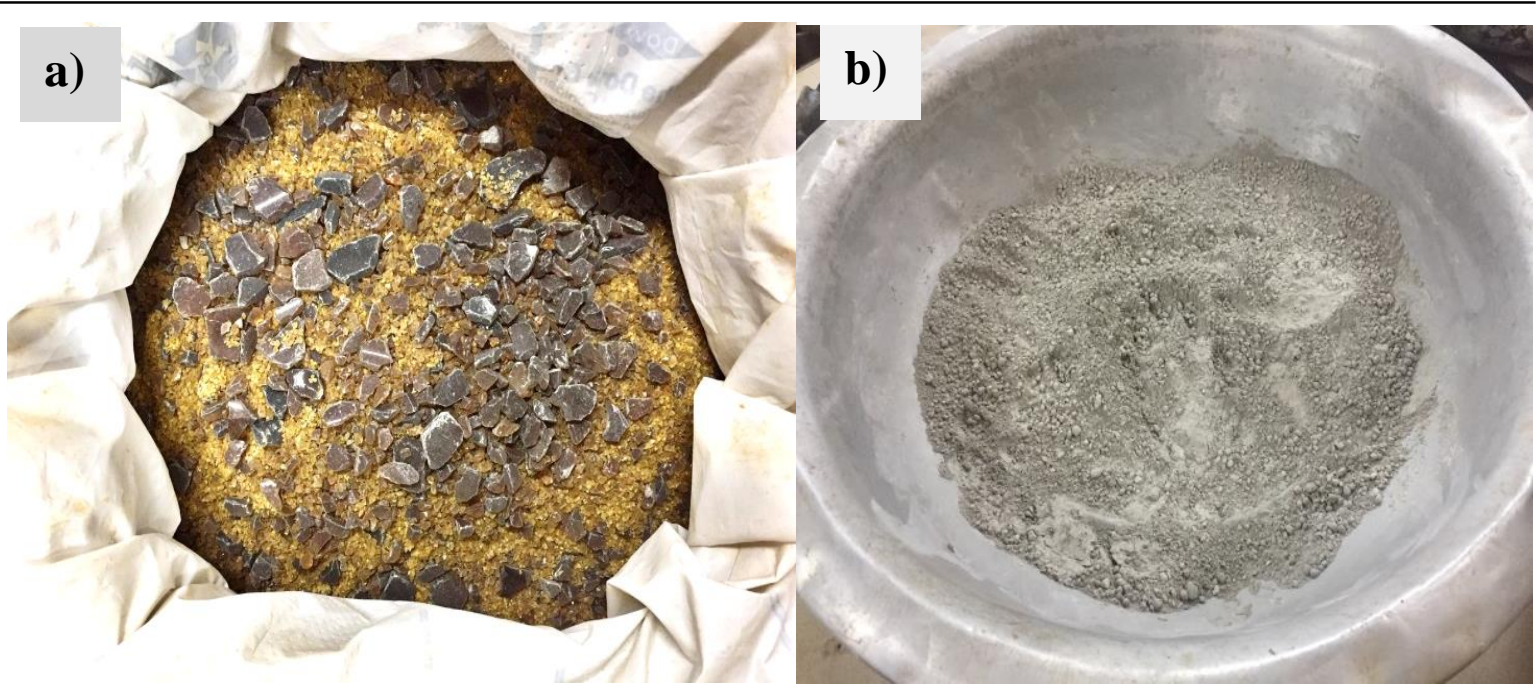

Figure 2: a) Glass Waste Crushed; b) Rock Dust Waste.

The natural material physical characterization followed the tests procedures: liquid limit [13], plastic limit [14], specific gravity [15], particle size distribution [16] and compaction test [17]. Concerning the chemical characterization and mineralogic composition of the material, the samples were analyzed by X-Ray Diffraction (XRD) and X-Ray Fluorescence Spectrometry (XRF).

\subsection{Sample preparation and mechanical procedures}

The specimens for UCS and tensile test were comprised of the clayey soil and pulverized glass waste or pulverized "rock dust" with $10 \%$ and $50 \%$ of dry soil mass. Thus, the samples were prepared in the following conditions:

I. Clayey soil $+10 \%$ of "rock dust" waste after high energy mill pulverization

II. Clayey soil $+10 \%$ of glass waste after high energy mill pulverization;

III. Clayey soil $+50 \%$ of "rock dust" waste after high energy mill pulverization;

IV. Clayey soil $+50 \%$ of glass waste after high energy mill pulverization

The apparatus consisted of a mold with standard dimensions of $100 \mathrm{~mm}$ diameter and $127 \mathrm{~mm}$ height. In order to perform one specimen for mechanical analysis, the following steps, based on the procedure of the compaction test, were adopted: (a) separation of $2 \mathrm{~kg}$ of natural soil, obtaining its hygroscopic water content and dry mass; (b) calculation of the waste content from the percentage chosen of $10 \%$ or $50 \%$ regarding to the dry soil mass; (c) addition of waste, respecting the $2 \mathrm{~kg}$ limit corresponding to the molds dimensions; (d) homogenization of the composition (soil + waste) by adding water until it reaches the optimum water content obtained in the compaction test; (e) compaction of the sample mixture according to the energy criteria. The specimens obtained were taken to the mechanical tests of Unconfined Compressive Strength (UCS) [18], and Tensile Strength (TS) [19]. In both procedures, the Universal Testing Machine (UTM 14) press of IPC Global was used. After the experiments were performed, the UCS, unconfined cohesion $(\mathrm{Cu})$ and Tensile Strength parameter were calculated through the equations 1,2 and 3 , respectively [20].

$$
\begin{aligned}
& U C S=\frac{4 F}{\pi d^{2}} \\
& G u=\frac{U C S}{2} \\
& T S=\frac{2 F}{\pi d h}
\end{aligned}
$$


On what:

$\mathrm{F}=$ axial rupture load

$\mathrm{d}=$ specimen diameter

$\mathrm{h}=$ average specimen height

\section{RESUlTS AND DiscuSSIONS}

\subsection{Soil and compositions characterization}

\subsubsection{Physical analyses}

The results of all physical characterization tests proposed in the methodology for both natural soil and mixtures with pulverized glass waste $(\mathrm{G})$ and pulverized "rock dust" residue $(\mathrm{R})$ are summarized in Table 1, followed by the particle size distribution shown in Figure 3.

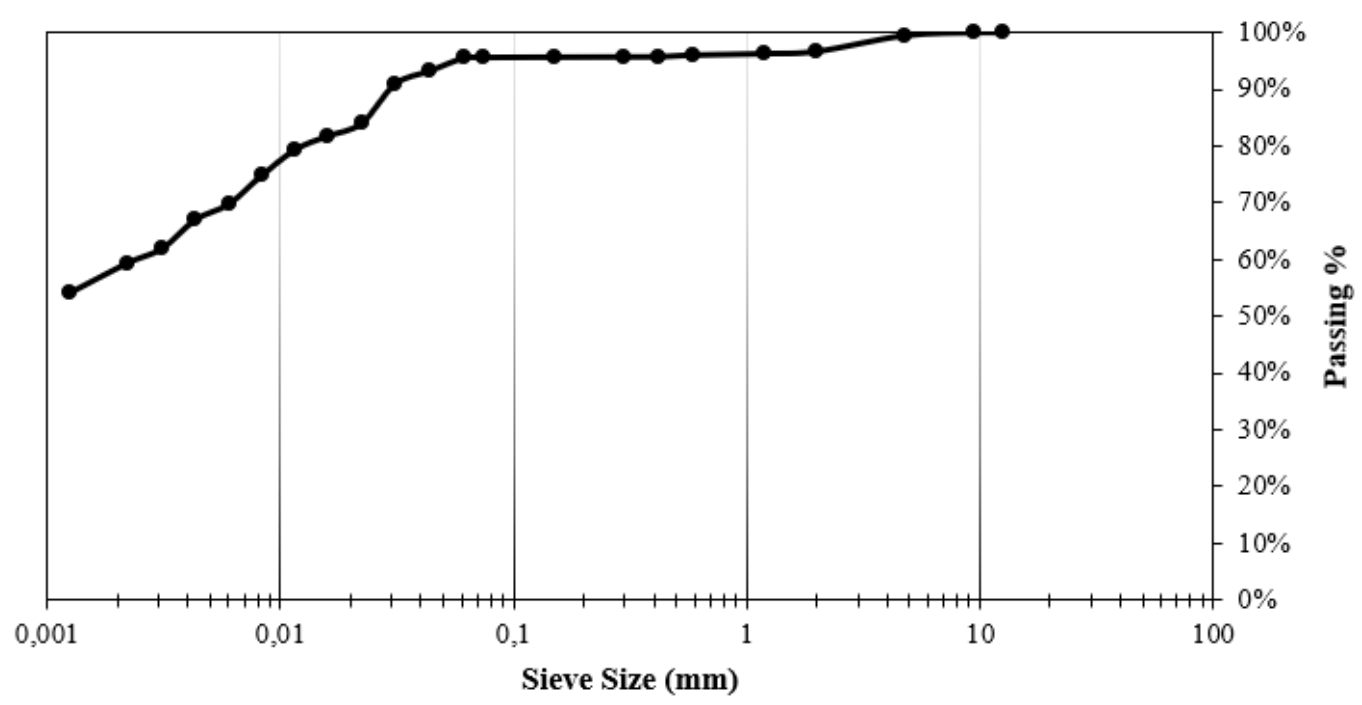

Figure 3: Particle size distribution of clayey soil.

Table 1: Particle size distribution of clayey soil.

\begin{tabular}{lccccc}
\hline \multicolumn{1}{c}{ PARAMETERS } & \multirow{2}{*}{ SoIL } & \multicolumn{2}{c}{ SOIL + G } & \multicolumn{2}{c}{ SOIL + R } \\
& & $\mathbf{1 0 \%}$ & $\mathbf{5 0 \%}$ & $\mathbf{1 0 \%}$ & $\mathbf{5 0 \%}$ \\
\hline PHYSICAL PROPERTIES & & & & & \\
Liquid Limit (\%) & 60.02 & 57.84 & 43.93 & 54.21 & 47.29 \\
Plastic Limit (\%) & 25.82 & 21.96 & 18.03 & 22.79 & 20.64 \\
Plasticity Index (\%) & 34.20 & 35.88 & 25.90 & 31.42 & 26.65 \\
Specific Gravity (g/cm3) & 2.55 & & & & \\
COMPACTION PROPERTIES & & & & & \\
Optimum water content (\%) & 22.01 & 19.61 & 15.10 & 15.65 & 12.41 \\
Maximum dry density $\left(\mathrm{g} / \mathrm{cm}^{3}\right)$ & 1.67 & 1.72 & 1.84 & 1.76 & 1.80 \\
\hline
\end{tabular}

It can be verified that in soils with liquid limit ranging from $35 \%$ to $100 \%$ and plasticity index between $20 \%$ to $40 \%$, there is a presence of kaolinite in the mineralogy matrix [20]. Also, according to Table 1, it was noted that the addition of glass and rock represented a decrease in plasticity index, yet it did not affect its classification as high plasticity soil. Based on results of particle size distribution and the Atterberg limits tests, the clayey soil was classified by Unified Soil Classification System (USCS) and American Association of State Highway and Transportation Officials (AASHTO) as CH (high plasticity clay) and A-7-5 (high plasticity clayey soil), respectively. Furthermore, soil-10\% glass waste and soil$10 \%$ rock dust samples were classified as high plasticity clay $(\mathrm{CH})$, while the mixtures with content of $50 \%$ have been classified as low plasticity clay (CL) [20]. 
The effects of glass waste and rock on the Atterberg limits are shown in Figure 4. Following the results, both liquid limit and plastic limit decreased by the addition of waste in mix ratio of $10 \%$ and $50 \%$. However, this decrease was more pronounced for LL, being equal to $16.09 \%$ and $12.73 \%$ for mixtures with $50 \%$ of $\mathrm{G}$ and $\mathrm{R}$, respectively, in relation to clayey soil. It was also noted that the plasticity index for the samples with $10 \%$ indicated greater reduction of plasticity relative to the mixtures with $50 \%$, having a reduction of $35.88 \%$ and $25.90 \%$ for $\mathrm{G}$ and $31.42 \%$ and $26.65 \%$ for $\mathrm{R}$, respectively.

a)

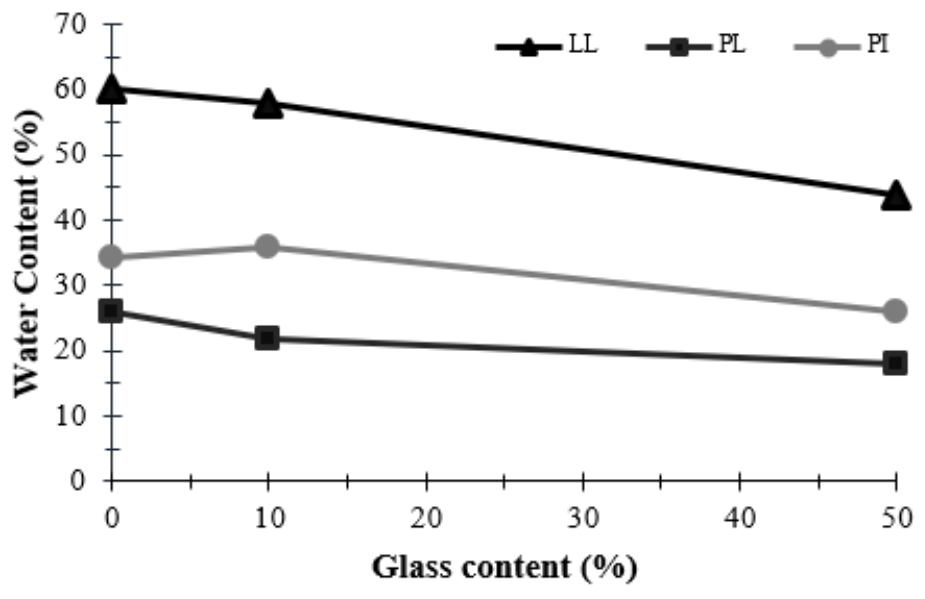

b)

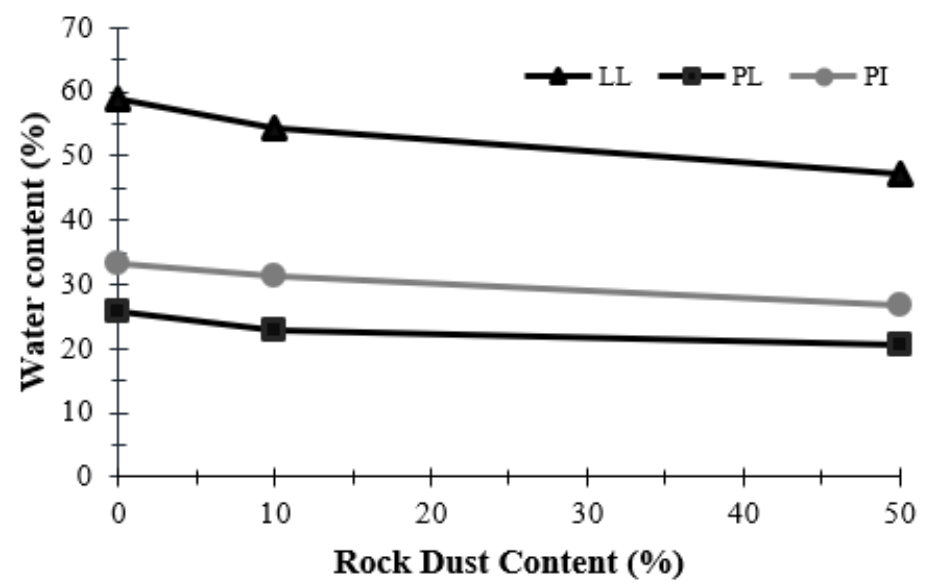

Figure 4: a) Atterberg parameters versus glass content b) Atterberg parameters versus rock dust content.

Concerning the compaction test, a result of optimum water content and dry density of $22.01 \%$ and 1.67 $\mathrm{g} / \mathrm{cm}^{3}$ respectively, was shown to the clayey soil. Such values are within the citations presented in the literature for lateritic clayey soils typical of the Amazon region [21]. Regarding the effects of glass on soil compaction (Figure 5), it was noted that the addition of $\mathrm{G}$ showed a decrease in the optimal water content and, consequently, an increase in the dry density, also consistent to previous study [22]. Figure 5 also shows a proportional relationship between the dry density to the glass content, reaching 1.72 $\mathrm{g} / \mathrm{cm}^{3}$ and $1.84 \mathrm{~g} / \mathrm{cm}^{3}$ for mix ratios of $10 \%$ and $50 \%$. Therefore, it represents an increase of $3 \%$ and $10.18 \%$ in relation to clayey soil, respectively.

When analyzing the implications of compaction in soil samples mixed with rock, the content of $10 \%$ resulted in a drop up to $30 \%$ in optimum water content, while the addition of $50 \%$ had a decrease of $45 \%$ (Figure 6). Regarding the dry density, the curves show that, as the rock dust content grows, the compaction parameter reaches its maximum value. Thus, when compared to clayey soil, the sample with $10 \%$ obtained $1.76 \mathrm{~g} / \mathrm{cm}^{3}$, an increase of $5.39 \%$, and the content with $50 \%$ reached $1.80 \mathrm{~g} / \mathrm{cm}^{3}$, increasing it at $7.78 \%$. Moreover, it is ensured that the optimum waste content decreases as the dry density increases with the addition of high-energy mill pulverized "rock dust" waste, in accordance with other works [23], [24]. 


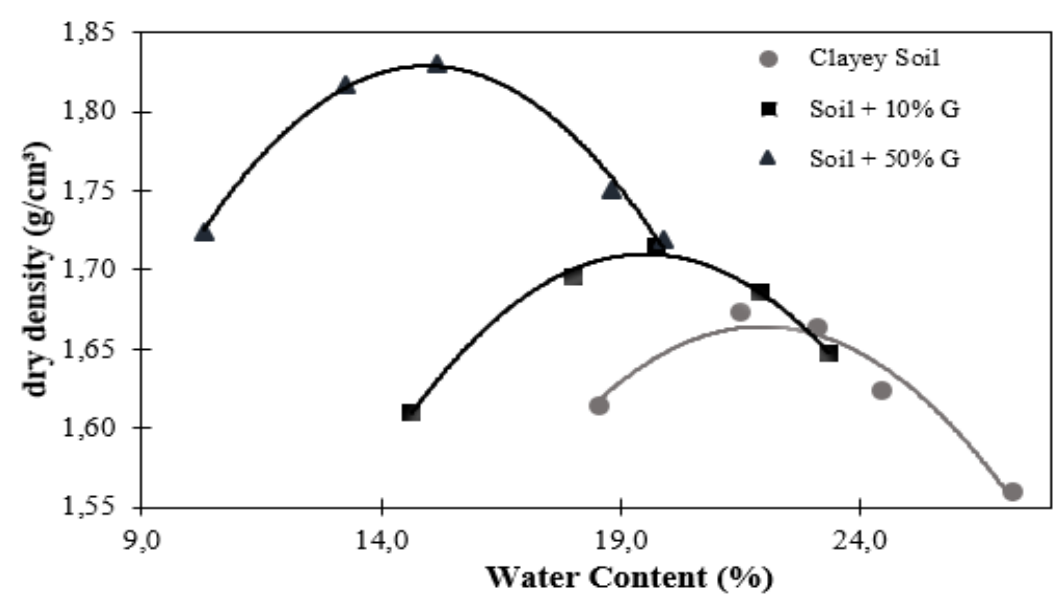

Figure 5: Compaction Curves for soil mixtures with glass.

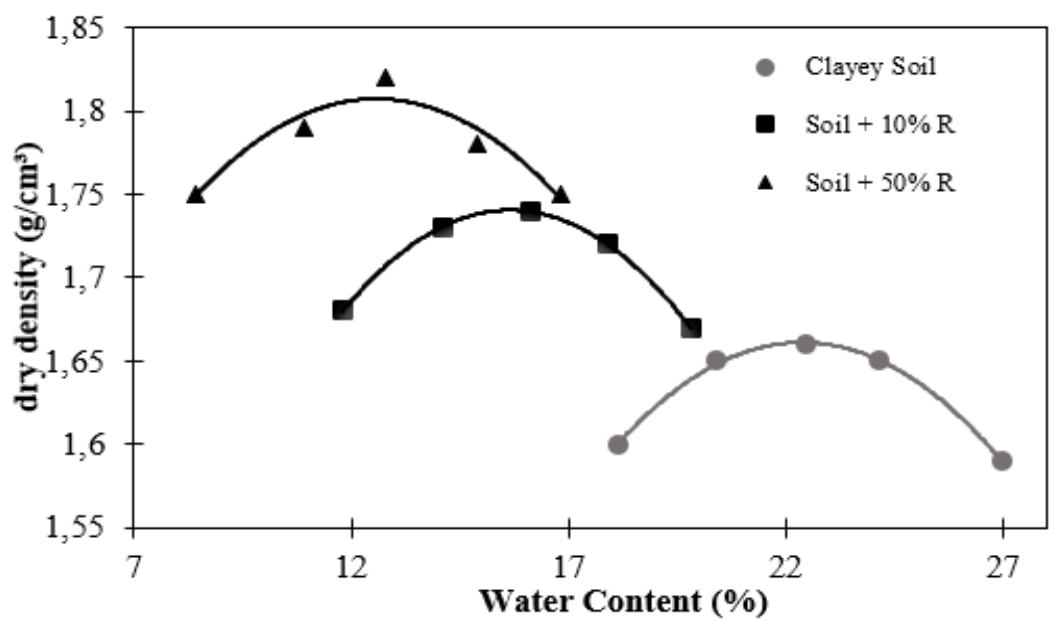

Figure 6: Compaction Curves for soil mixtures with rock.

\subsubsection{Chemical and Mineralogical Analysis}

Regarding the chemical composition of the materials, Table 2 shows the fractions of each component present in soil, glass and rock dust waste based on the XRF experiment, having silica as the main component. Similarly, the XRD graphs presented in Figure 7 show similar peaks in all cases, with emphasis on the presence of kaolinite and quartz minerals predominant in all compositions. Also, the high intensities of the quartz peaks between $2 \theta$ of $20^{\circ}$ and $30^{\circ}$ can be emphasized, and the less intense and wider peaks of kaolinite, characteristic of fine soils such as those found in the Amazon, as it was labeled.

Table 2: Concentration of chemical components of materials.

\begin{tabular}{cccc}
\hline CHEMICAL PROPERTIES & SOIL & GLASS & $\begin{array}{c}\text { ROCK } \\
\text { DUST }\end{array}$ \\
\hline Silica $\left(\mathrm{SiO}_{2}\right)(\%)$ & 61.012 & 71.587 & 70.277 \\
Alumina $\left(\mathrm{Al}_{2} \mathrm{O}_{3}\right)(\%)$ & 24.416 & 1.443 & 11.608 \\
Iron oxide $\left(\mathrm{Fe}_{2} \mathrm{O}_{3}\right)(\%)$ & 9.893 & 1.095 & 5.144 \\
Potassium oxide $\left(\mathrm{K}_{2} \mathrm{O}\right)(\%)$ & 1.925 & 1.215 & 9.955 \\
Calcium oxide $(\mathrm{CaO})(\%)$ & 0.227 & 22.856 & 1.705 \\
Others & 2.527 & 1.804 & 1.311 \\
\hline
\end{tabular}




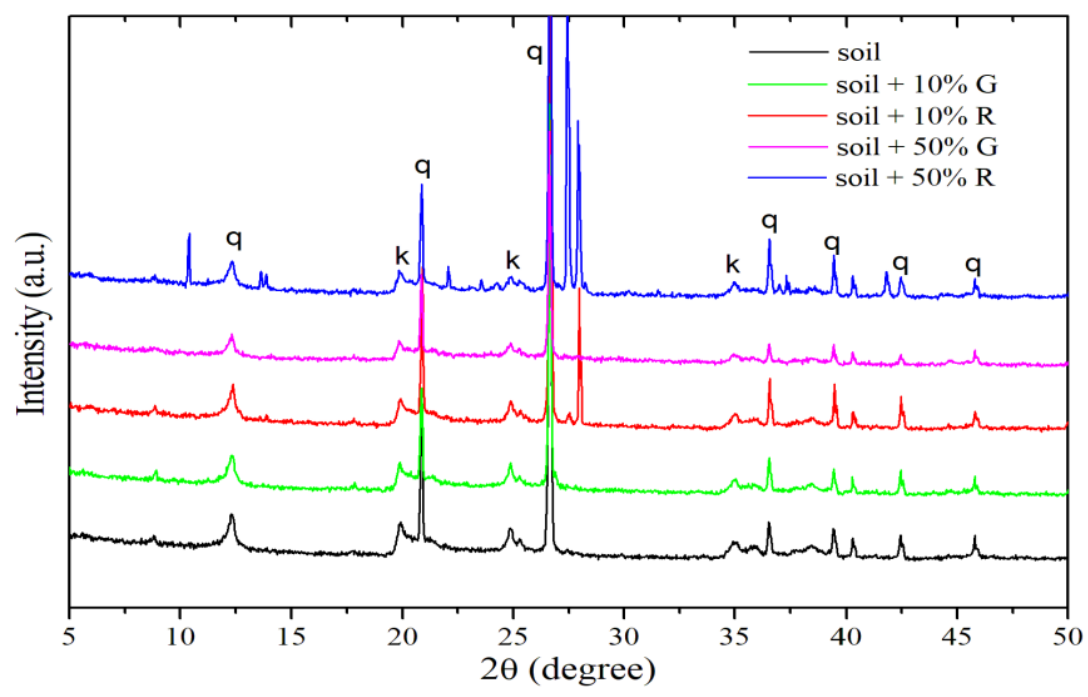

Figure 7: XRD for soil samples. Label: k (kaolinite); q (quartz).

\subsection{Soil and compositions characterization}

\subsubsection{Effect of glass and rock on compressive strength}

According to the glass content (Figures 8), it is recorded that, in comparison to clayey soil, the UCS increased in the soil $+10 \% \mathrm{G}$ and decreased with the addition of $50 \%$ waste in soil. Based on Equation 1, the UCS values were equal to $561.50 \mathrm{kPa}, 682.46 \mathrm{kPa}$ and $511.31 \mathrm{kPa}$ for soil, soil $+10 \% \mathrm{G}$ and soil $+50 \% \mathrm{G}$, respectively. Concerning the unconfined cohesions $(\mathrm{Cu})$, calculated according to Equation 2, the results were $280.75 \mathrm{kPa}, 341.23 \mathrm{kPa}$ and $255.66 \mathrm{kPa}$ for soil, soil $+10 \% \mathrm{G}$ and soil $+50 \% \mathrm{G}$, respectively. Regarding the compressive strength, it is confirmed that glass waste was legitimized as a particle size stabilizer with content of $10 \%$, as its UCS increased to $21.5 \%$ compared to clayey soil. This fact can be explained by the performance of the main component of glass, silica (SiO2) [4], which provided greater internal friction in the mixture. However, it is noteworthy that the increase of this parameter affects up to a certain percentage, since the soil $+50 \% \mathrm{G}$ had a decrease in the UCS.

On the other hand, the mechanical evaluation of UCS to the pulverized rock dust was satisfactory in both samples when compared to the soil, as shown in Figure 9. The calculated compressive strength values were $900.44 \mathrm{kPa}$ and $869.01 \mathrm{kPa}$ for soil $+10 \% \mathrm{R}$ and soil $+50 \% \mathrm{R}$, respectively. Such additions represent a percentage of increase of $60.3 \%$ and $54.8 \%$ of the UCS relative to soil. Moreover, unconfined cohesions reached $450.22 \mathrm{kPa}$ and $434.51 \mathrm{kPa}$ results for $10 \%$ and $50 \%$ of rock dust. Therefore, the results are in accordance with the studied literature, in which insertions of polymeric material indicate an increase in the value of UCS among 15\% to 70\% [25]. In other studies, it was found that the increase in UCS varies according to soil type and waste [15]. These conclusions came from papers that: a) showed the addition of $20 \%$ of fly ash obtained UCS $=95 \mathrm{kPa}$ [26]; b) reported an UCS $=564.6 \mathrm{kPa}$ adding $6 \%$ sugar cane ash [27]; and c) pointed out an a value of UCS $=150 \mathrm{kPa}$ when mixing $45 \%$ stone dust and fly ash [28]. 


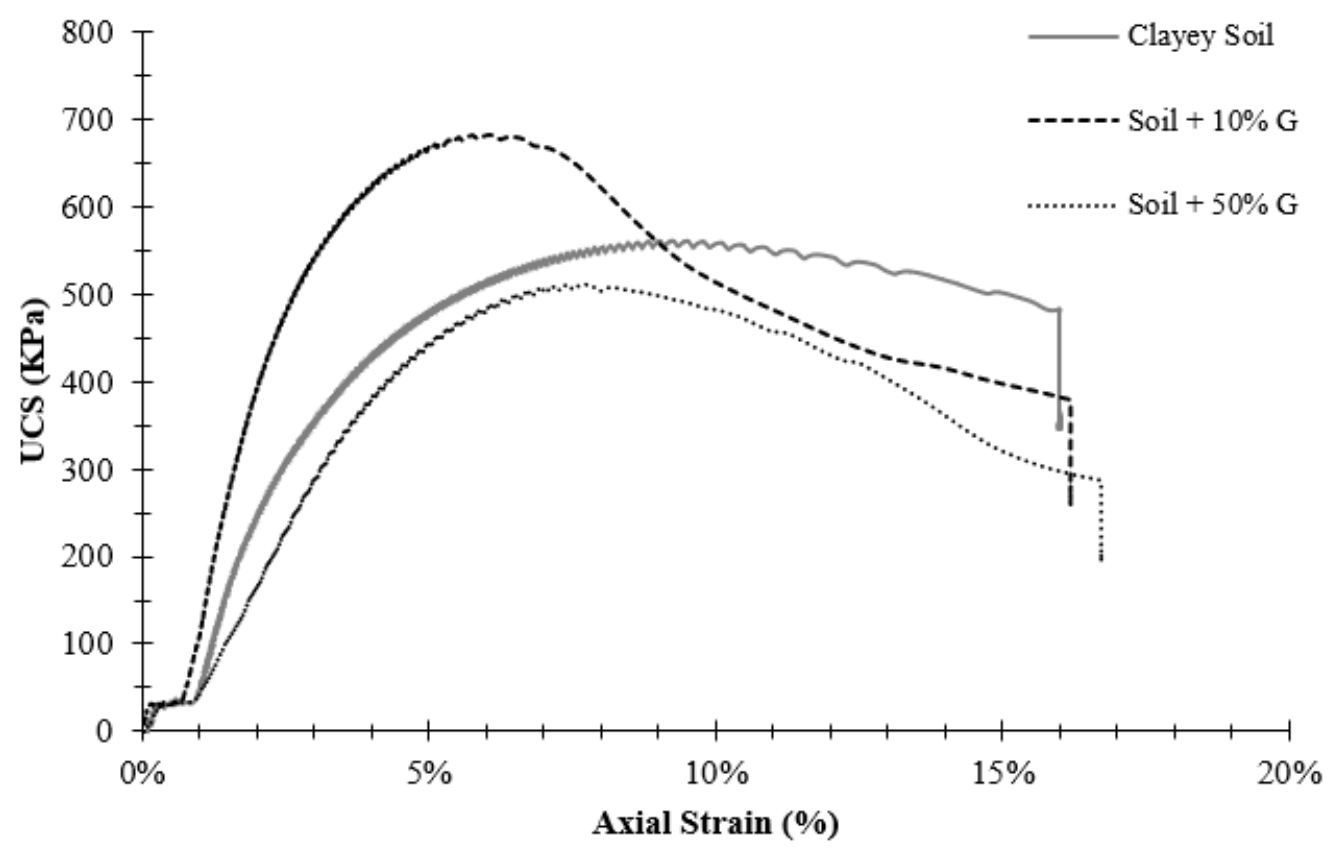

Figure 8: Effect of glass waste on UCS tests.

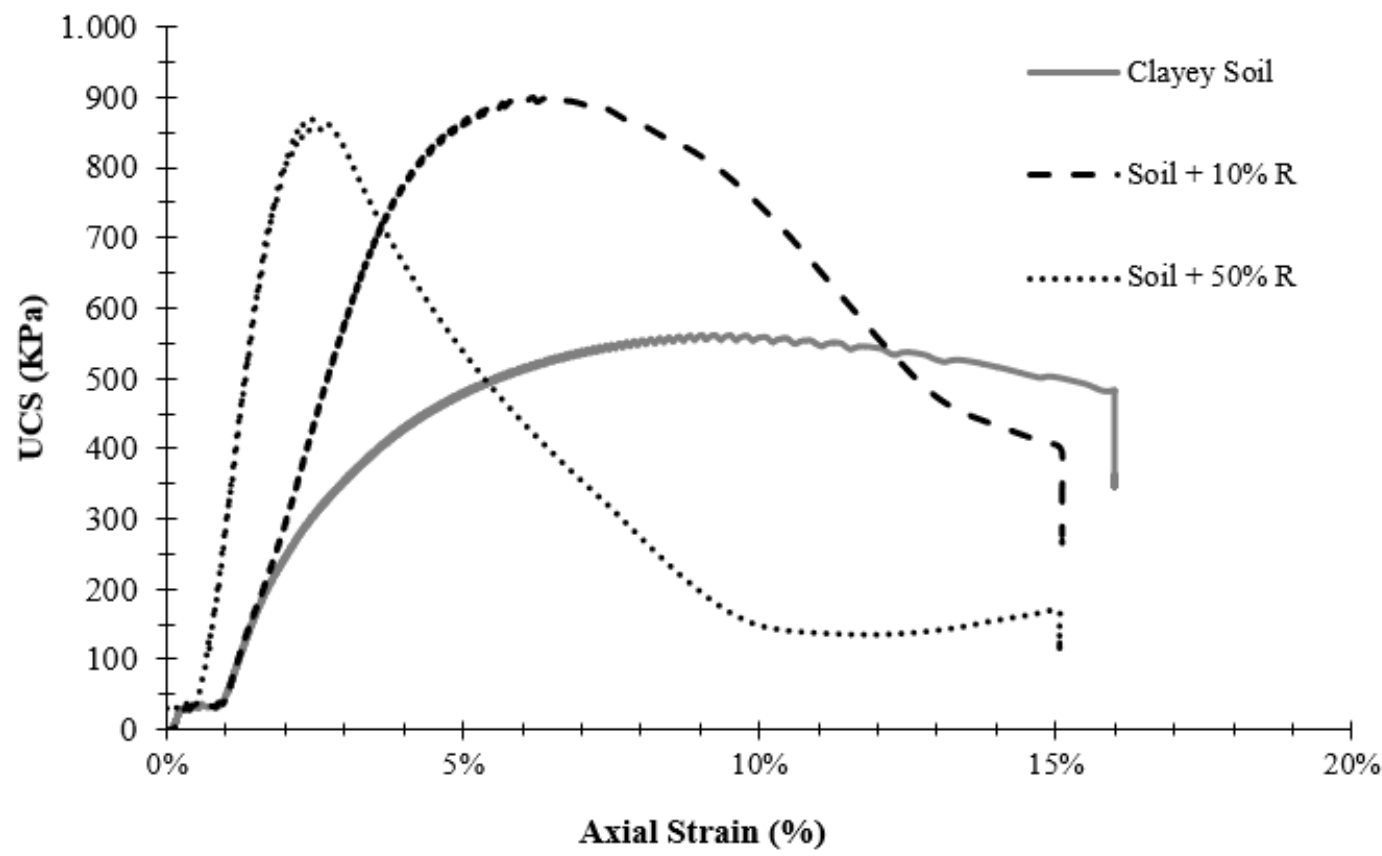

Figure 9: Effect of rock dust on UCS tests.

\subsubsection{Effect of glass and rock on tensile strength.}

Regarding the effects of glass as stabilizer on tensile strength, Figure 10 shows that although the soil + $50 \% \mathrm{G}$ obtained a decrease in TS compared to clayey soil, the specimen with $10 \%$ of the pulverized glass increased its strength in $6 \%$. According to Equation 3, the results of TS were $116.40 \mathrm{kPa}, 123.0$ $\mathrm{kPa}$ and $64.5 \mathrm{kPa}$ for soil, soil $+10 \% \mathrm{G}$ and soil $+50 \% \mathrm{R}$, respectively. Thus, the great impact in this test is highlighted on the effect of $50 \%$ of glass in the mixture that showed a sharp decrease in its strength.

Analyzing the compositions with rock dust, the mechanical behavior of TS achieved better results for the composition pertinent to the $10 \%$ waste addition, where the TS increased $8.43 \%$ related to the clayey 
soil. In contrast, tests with $50 \%$ of soil stabilized with rock expressed a decrease of $30.20 \%$. The effect of rock dust in soil are shown in Figure 11. According to other studies, the maximum tensile strength values cited were around $100 \mathrm{kPa}$ for $6 \%$ polymer stabilized clay-sandy soil. Therefore, it is consistent with the results of the current work in question, in which strengths of $123 \mathrm{kPa}$ and $126 \mathrm{kPa}$ for samples with soil $+10 \% \mathrm{G}$ and soil $+10 \%$ R respectively [25] were obtained.

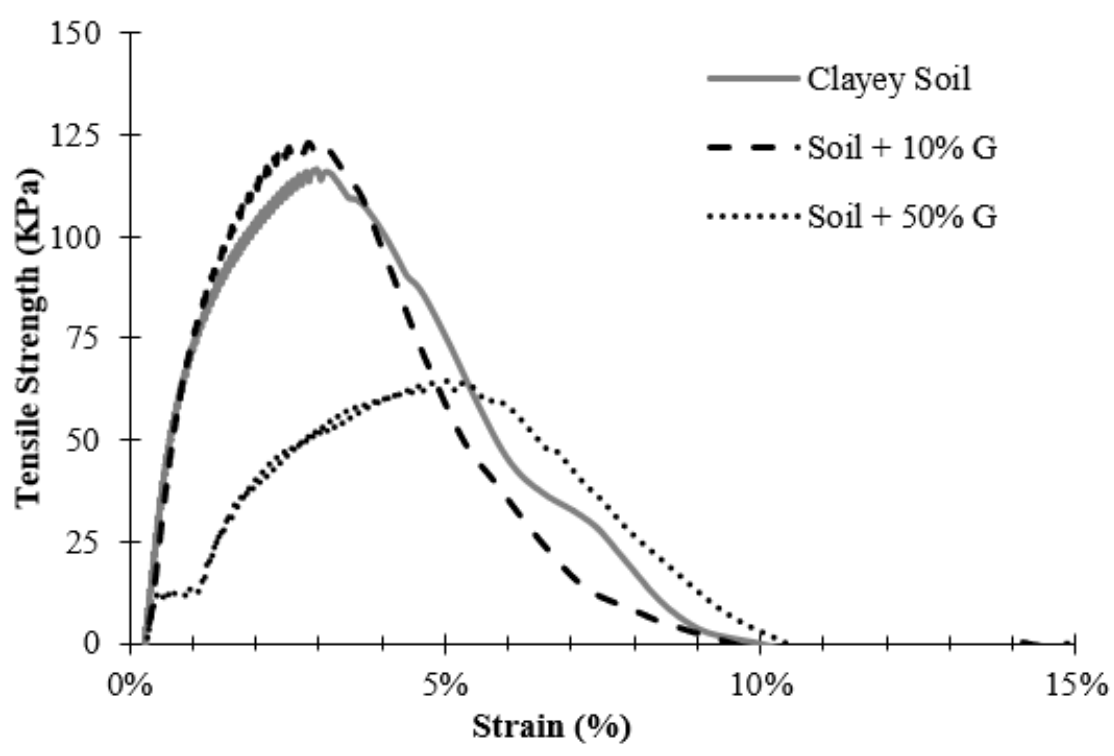

Figure 10: Effects of glass waste on TS tests.

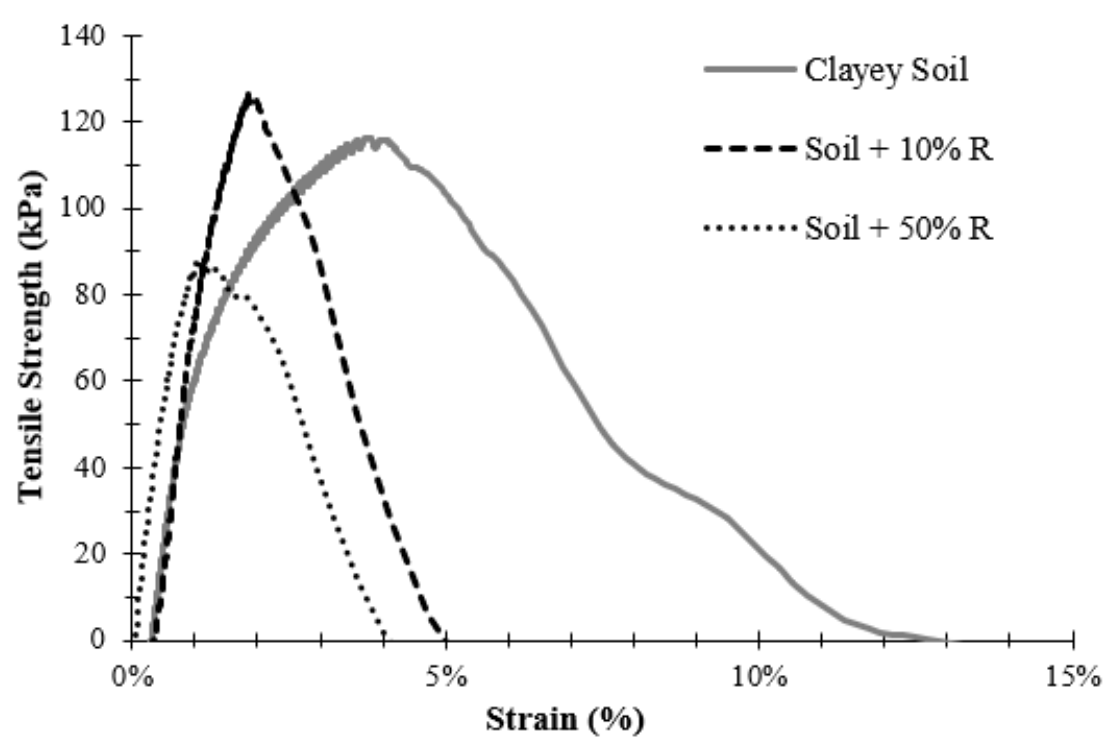

Figure 11: Effects of rock dust waste on TS tests.

With respect to UCS test, the specimens were axially compressed and without confinement, and, in case of the present work, Figure 12a shows that their rupture occurred at an angle of $45^{\circ}$. Allusive to TS, loading is carried out between two narrow and opposite plates, generating a relatively uniform tensile stress perpendicular to the diametrical plane causing a breakout [29], as shown in Figure 12b. It is notable that the literature presents investigations on relationships between such parameters [30]. Based on this research, the relationship between the UCS of the wastes contents and the UCS of the clayey soil were determined in the present study, and, similarly, the same ratio between tensile strengths (TS) for formulations with and without stabilizers. Similar behavior was verified for both cases, as well as higher values in the UCS tests, especially in the soil + 10\% R mixture (Figure 13). 


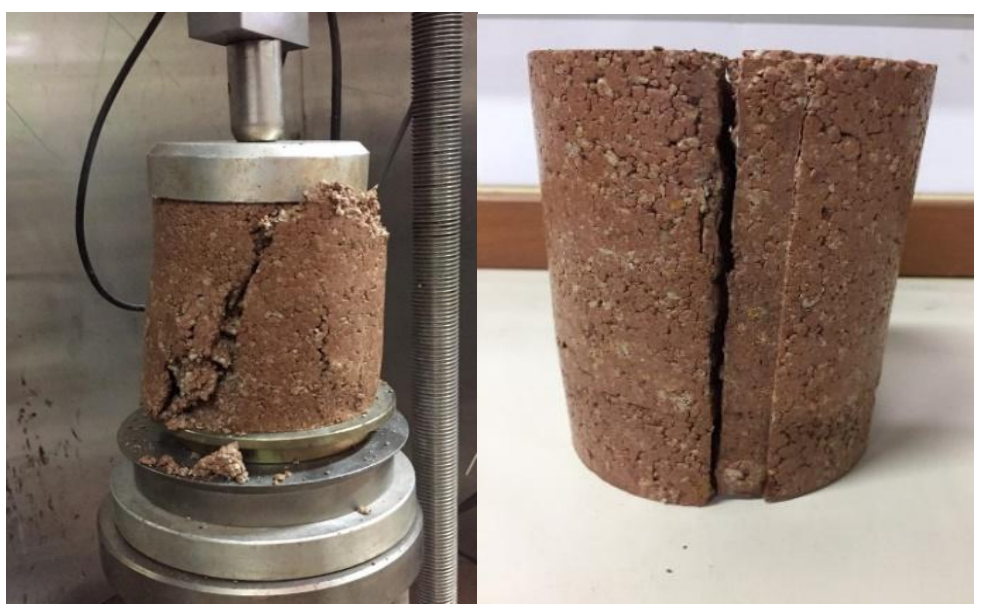

Figure 12: Rupture of specimens: (a) UCS test; (b) Tensile Strength test.

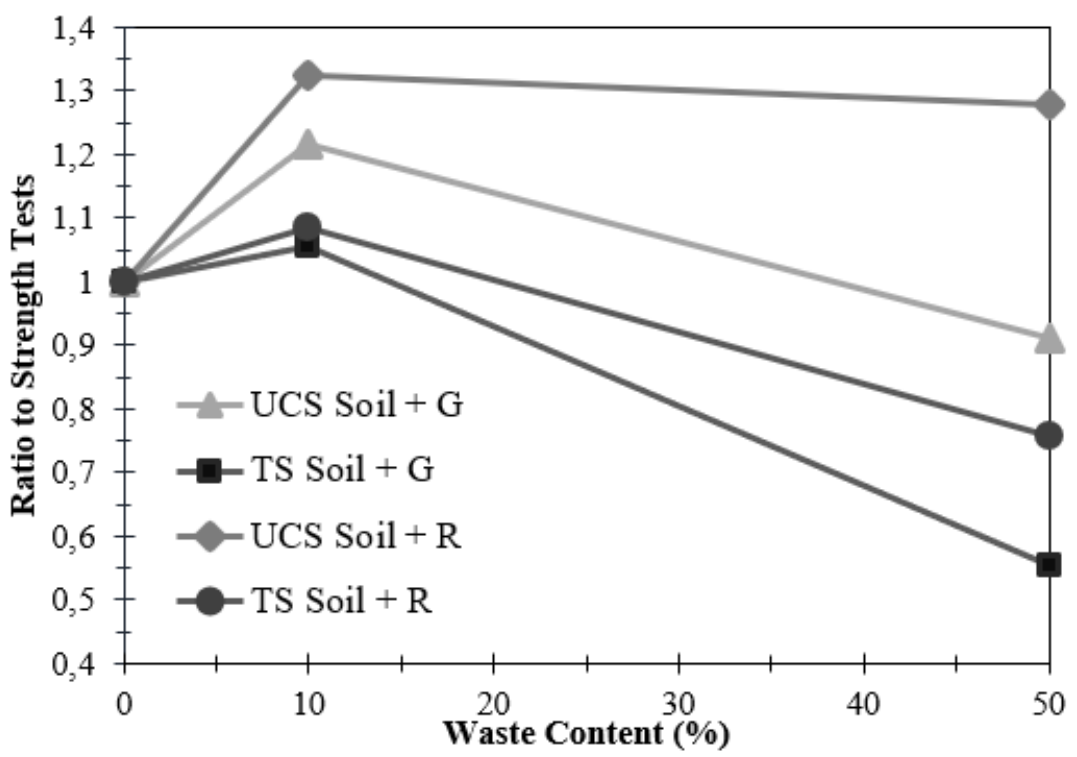

Figure 13: Ratio between mechanical tests.

\section{CONClusions}

The present work investigated the mechanical behavior of a typical clayey soil from Amazonas that is used for the production of ceramic pieces, when mixed with pulverized glass waste and pulverized "rock dust" in a high energy mill, through physical and mechanical tests. According to characterization tests and mechanical behavior, the observations and conclusions can be summarized as follows:

- The inclusion of waste in soil decreased the plasticity index and the optimum water content, as well as increased dry density of the sampled soil;

- The addition of both wastes did not result in divergence of the typical clayey behavior according to literature standards;

- The wastes were effective stabilizers for soils with typical characteristics of plastic clays, considering the sensitive alterations in relation to their physical indexes;

- The stabilization technique achieved greater efficiency by employing a $10 \%$ increase in both glass waste and "rock dust". Mechanical analysis responded with higher values for the Unconfined Compressive Strength (UCS), with a significant increase, and for the tensile strength (TS) related to the clayey soil; 
- The use of nanoparticulate materials in the geotechnical area is promising as to the achievement of more refined levels of mechanical resistance;

- Confronting both stabilizers, the pulverized rock dust waste showed greater strengths parameters in both investigated mechanical tests.

Finally, based on the investigation with wastes, it is inferred that environmental passive can be used to improve the strength of clayey soils, and it is proved to be ecological and responsible solutions that guarantee good results.

\section{ACKNOWLEDGEMENTS}

The authors would like to thank the Laboratory of Materials (LABMAT - "Laboratório de Materiais") for helping us to perform and analyze X-ray diffraction (XRD) tests.

\section{REFERENCES}

[1]. Latifi, Nima et al. Tropical residual soil stabilization: A powder form material for increasing soil strength. Construction and Building Materials, v. 147, p. 827-836, 2017.

[2]. Nogami, J. S.; Villibor, D. F. Algumas Comparações entre uma nova Classificação de Solos e as Tradicionais, principalmente para Finalidades Rodoviárias. In: VII Congresso Brasileiro de Mecânica dos Solos e Engenharia de Fundações, ABMS. Recife. 1982. p. 160-173.

[3]. Ghasabkolaei, Navid et al. Geotechnical properties of the soils modified with nanomaterials: A comprehensive review. Archives of Civil and Mechanical Engineering, v. 17, n. 3, p. 639-650, 2017.

[4]. Kalkan, Ekrem; Akbulut, Suat. The positive effects of silica fume on the permeability, swelling pressure and compressive strength of natural clay liners. Engineering Geology, v. 73, n. 1-2, p. 145156, 2004.

[5]. Bahmani, Sayed Hessam Et Al. Stabilization of Residual soil using SiO2 nanoparticles and cement. Construction and Building Materials, v. 64, p. 350-359, 2014.

[6]. Mostafa, A.; Ouf, Mohamed S.; Elgendy, M. Stabilization Of Subgrade Pavement Layer Using Silica Fume and Nano Silica. International Journal of Scientific \& Engineering Research, v. 7, n. 3, 2016.

[7]. Mousavi, Seyed Esmaeil. Utilization of Silica Fume to Maximize the Filler and Pozzolanic Effects of Stabilized Soil with Cement. Geotechnical and Geological Engineering, v. 36, n. 1, p. 77-87, 2018.

[8]. Zhang, Guoping. Soil nanoparticles and their influence on engineering properties of soils. In: Advances in Measurement and Modeling of Soil behavior. 2007. p. 1-13.

[9]. Khalid, Norazlan Et Al. Influence Of Nano-Soil Particles In Soft Soil Stabilization. Electronic Journal of Geotechnical Engineering, Malaysia, v. 20, n. 2, p.731-738, jan. 2015.

[10]. Sabat, Akshaya Kumar; Pati, Subasis. A review of literature on stabilization of expansive soil using solid wastes. Electronic Journal of Geotechnical Engineering, v. 19, n. Bund U, 2014.

[11]. ABNT. NBR 6457: "Amostras de solo-preparação para ensaios de compactação e ensaios de caracterização". ABNT, 2016.

[12]. CPRM (2006) Geologia e Recursos Minerais do Estado do Amazonas. http://www.cprm.gov.br/publique/?tpl=home, acessado em 09/09/2018.

[13]. ABNT. NBR 6459: Determinação do Limite de Liquidez. ABNT, 2017.

[14]. ABNT. NBR 7180: solo: determinação do limite de plasticidade: método de ensaio. ABNT, 2017.

[15]. ABNT. NBR 6508: grãos de solos que passam na peneira de 4, $8 \mathrm{~mm}$ : determinação da massa específica: método de ensaio. ABNT, 1984.

[16]. ABNT, N. NBR 7181-Solo-Análise granulométrica. Rio de Janeiro, 2017.

[17]. ABNT. NBR 7182: Solo: Ensaio de compactação. Rio de Janeiro, 2016.

[18]. ABNT. NBR 12770. Solo coesivo - Determinação da resistência à compressão não confinada. Rio de Janeiro, 1992.

[19]. ASTM D3967-16: Standard test method for splitting tensile strength of intact rock core specimens. ASTM International, West Conshohocken, USA, 2016.

[20]. Das, Braja M. Et Al. Fundamentos De Engenharia Geotécnica. São Paulo: Thomson Learning, 2014.

[21]. Lovato, Rodrigo Silveira. Estudo do comportamento mecânico de um solo laterítico estabilizado com cal, aplicado à pavimentação. 2004. 164 f. Dissertação (Mestrado) - Curso de Engenharia Civil, Universidade Federal do Rio Grande do Sul, Porto Alegre, 2004.

[22]. Fauzi, Achmad; Rahman, Wan Mohd Nazmi Wan Abdul; Jauhari, Zuraidah. Utilization waste material as stabilizer on kuantan clayey soil stabilization. Procedia engineering, v. 53, p. 42-47, 2013. 
[23]. Ramadas, T.L Et Al.(2010). Swelling and strength characteristics of expansive soil treated with stone dust and fly Ash. In: Indian Geotechnical Conference-2010, GEOtrendz,16-18 December, Bombay, pp 557-560.

[24]. Sivrikaya, Osman; Karaca, Zeki. Recycling waste from natural stone processing plants to stabilise clayey soil. Environ Earth Sci, N/a, v. 71, n. /, p.4397-4407, out. 2013. Disponível em: <https://link.springer.com/content/pdf/10.1007/s12665-013-2833-x.pdf>. Acesso em: 13 abr. 2018.

[25]. Machado, L. F. M. Et al. (2017) Adição de uma associação polimérica a um solo argilo-arenoso com vistas à estabilização química de materiais para pavimentos. Matéria (Rio de Janeiro), [s.1.], v. 22, n. 3, p.1-13, 10 ago. FapUNIFESP (SciELO)

[26]. Sabat, Akshaya Kumar; Pradhan, Abinash. Fiber Reinforced-fly ash stabilized expansive soil mixes as subgrade material in flexible pavement. Electronic Journal of Geotechnical Engineering, v. 19, p. 5757-5770, 2014.

[27]. Amu, O. O.; Ogunniyi, S. A.; Oladeji, O. O. Geotechnical properties of lateritic soil stabilized with sugarcane straw ash. American journal of Scientific and industrial Research, v. 2, n. 2, p. 323-331, 2011.

[28]. Sabat, Akshaya Kumar; Bose, Bidula. Improvement in Geotechnical properties of an Expansive soil using Fly ash-Quarry dust Mixes. Electronic Journal of Geotechnical Engineering, v. 18, p. 34873500, 2013.

[29]. Gopala Krishnayya, A. V.; Eisenstein, Zdenek; Morgenstern, Norbert R. behavior of compacted soil in tension. Journal of Geotechnical and Geoenvironmental Engineering, v. 100, n. Proc. Paper 10828, 1974.

[30]. Correia, António As; Oliveira, Paulo J. Venda; Custódio, Dione G. Effect of polypropylene fibres on the compressive and tensile strength of a soft soil, artificially stabilised with binders. Geotextiles and Geomembranes, v. 43, n. 2, p. 97-106, 2015.

\section{AuTHORS}

Fábio Gusmão is an undergraduate student in Civil Engineering from Federal University of Amazonas since 2015. In 2018, he joined the Research Group of Geotechnical Engineering and developed studies mainly in geotechnical and pavement areas, receiving a scholarship from $\mathrm{CNPq}$, federal agency of fomentation to research in Brazil.

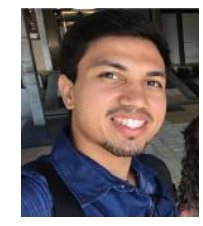

Consuelo Frota is a professor in department of Civil Engineering from Federal University of Amazonas. She received her M.S. and PhD degree in Transportation Engineering in 1981 and 1985, respectively. In 1995, she founded the Research Group of Geotechnical Engineering and, since then, has been leading studies in geotechnics and pavements with emphasis to new materials to construction. 